\title{
Distribution and species composition of the littoral interstiticial free living nematodes in the northern Red Sea, Egypt
}

\author{
Ashraf I. Ahmed; Diaa Eddien A. Mohammed and \\ Mahmmoud H. Hanafy \\ Marine Science Department, Faculty of Science, Suez Canal University, \\ Ismailia, Egypt. \\ E-mail address: diaameiobenthos@yahoo.com
}

\begin{abstract}
$\mathrm{F}$ ree living nematodes represent the most abundant and diversified group of the interstitial meiobenthos in the northern Red Sea, where their contribution ranged between 38 and $100 \%$ of total count of all interstitial organisms. Nematodes distribution, abundance and species composition in the Egyptian Red Sea were studied during winter, 2006. Nematodes abundance ranged between 8 and 163 organisms $/ 10 \mathrm{~cm}^{2}$. The intertidal zonation was investigated and showed increasing in the average density of nematodes toward low tide mark (sublittoral zone). A total of 79 nematode species were recorded; xyalid and oncholaimid were the most abundant families contributing $12 \%$ for each of total nematodes count. Densities of nematodes were affected by the grain size of the sediment, TOMs and redox potential (Eh). Also, pollution and landfilling have the most drastic effect on their abundance and diversity.
\end{abstract}

Keywords: Free living nematodes, distribution, abundance, zonation, community structure, Red Sea.

\section{INTRODUCTION}

Most of ecological studies on the littoral zones have been restricted to the macrofauna, while the interstitial meiofauna has received little attention (McLachlan and Jaramillo, 1995). Studies have focused mainly on higher taxa level, while those on species level are scarce (Olfasson, 1991; Rodrigues et al., 2001). Nematodes are the most abundant metazoans in marine sediments (Nicholas, 2001), only few studies apart from purely taxonomic ones, have described the nematode species composition of sandy beaches (Platt and Warwick, 1980; Blome, 1983). This is probably due to the time consuming research and the overall high densities of nematofaunal assemblages. Theoretically, nematodes are an excellent taxon to be used as ecological indicators for benthic environment (Heip et al., 1985). They reach to very high density, so a small sediment sample yields enough animals to make 
scientifically sound statements. They have ubiquitous distribution, high diversity (with a range from very tolerant to highly sensitive species), short generation time and a continuous reproduction (Giere, 2009).

No work has, so far, been done on the sandy beach interstitial meiofauna of the Egyptian Red Sea beaches, in particular free living nematodes. So, the current study aimed to study the distribution status of the littoral free living nematodes in the Egyptian Red Sea as well as the species composition.

\section{Study area}

\section{MATERIALS AND METHODS}

Twenty one sites were visited along the Egyptian coast of the northern Red Sea (Fig. 1). All selected sites were located at Red Sea Governorate; 16 sites were located on the coastal areas in addition to five sites on the coastal Islands of the northern Red Sea. Selection of sites was done considering the following factors: 1) Nature of shore such as: sandy bottom habitat (represented by Sama Beach, El Giftun 2, Abo Menqar, Marsa Alam, Um El Abass and Hamata), mangrove habitat (Abo Menqar mangrove, Safaga and Al Qulaan), seagrass meadows (Al Gemsha and Shalateen) and seaweed bottom (Marsa Ghaleb), 2) Human Impact such as: touristic activity (Helnan Reagena, El Giftun 1 and Kiriazi), exportation ports (Al Hamraween and Abo Tartoor) and dockyards (Al Azaq Al Qadeem, Gabal El Zeit) and one with no impact of any sort (Wadi El Gemal Island).

The investigated sites were classified according to McLachlan (1980) in relation to exposure as follows: a- Sheltered or protected beaches, with little wave action; represented by Gabal El Zeit, Al Azaq Al Qadeem, Safaga, Sharm El Luli and Al Qulaan Sites). b- Exposed beaches including other sites with different wave actions).

\section{MEASUREMENTS OF PARAMETERS}

Water temperature was measured by inserting a glass mercury thermometer $\left(110^{\circ} \mathrm{C}\right)$ graduated to $0.5^{\circ} \mathrm{C}$ into the surface layer of each zone for 2 minutes. The salinity of the sample was measured using a calibrated refractrometer (ATAGO S/Mill, Model, 8607-0-100 \%o).

Sediment samples (100 g of sediments) were collected by hand metal corer at each zone per site for grain size analysis of sediments followed the method described by Folk (1974), the mean grain size and other granulometric statistics were calculated using methods of Folk and Ward (1957). TOMs for each site were determined by combustion of 1 $\mathrm{g}$ of fine sediment $(\mathrm{Mz}=+2 \varphi)$ then dried at $60^{\circ} \mathrm{C}$ for 12 hours. Organic matter was then assessed as the percentage weight loss in the samples after combustion at $500{ }^{\circ} \mathrm{C}$ for 24 Hours (Holme and McIntyre, 1984).

Hydrogen ion concentration $(\mathrm{pH})$ and Redox potential $(E h)$ were measured in the field using a pocket $\mathrm{pH} / \mathrm{mV}$ meter, Orion 210 . This 
instrument was calibrated using standard buffer solution (7 and $9 \mathrm{pH})$ before using. The electrode was dipped in water for a minute before recording the reading for the ion concentration. Another probe was immersed into the sediments core to record the redox potential $(E h)$ reading for a minute. Three replicate measures were done and the mean reading was calculated. $\mathrm{DO}_{2}$ was determined by Winkler method (Strickland and Parson, 1968).

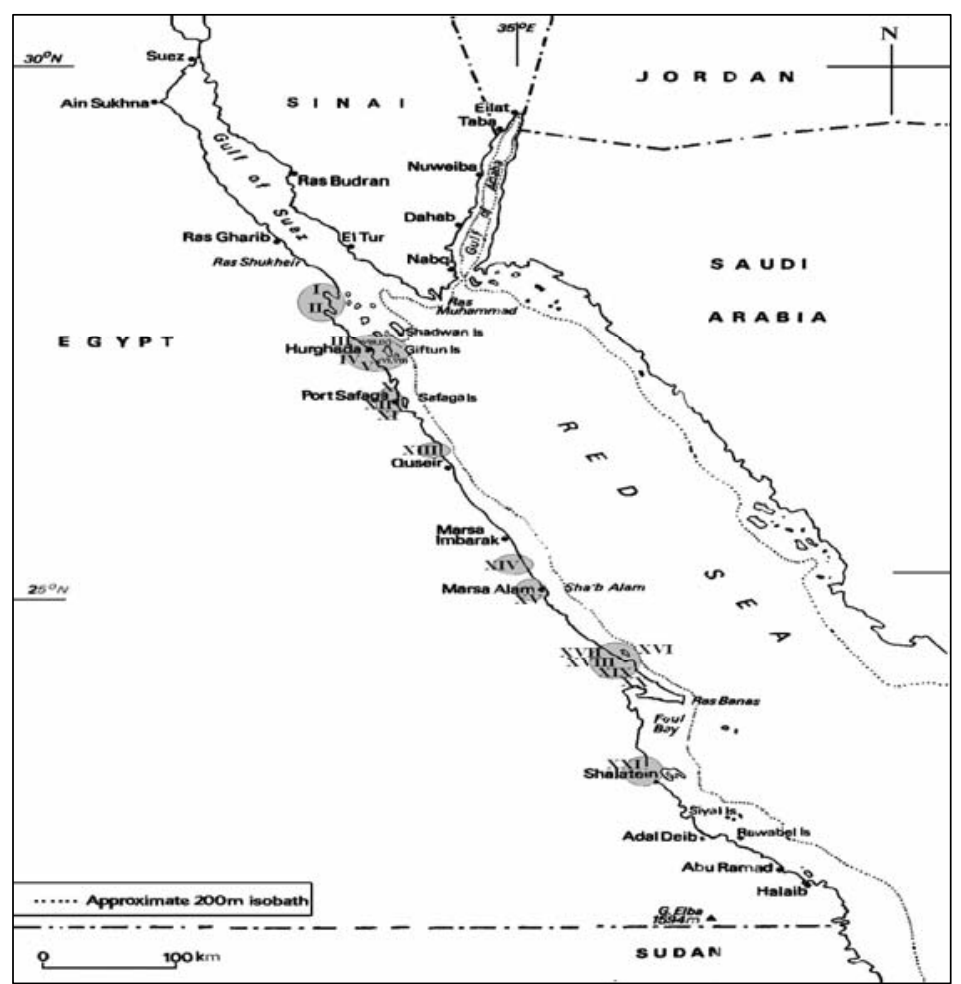

Fig. 1: Sampling sites along the coast of the northern Red Sea (I. Gabal El Zeit, II. Al Gemsha, III. Sama Beach, IV. Al Azaq, V. Helnan Regena, VI. Abo Menqar Island, VII. Abo Menqar Island Mangrove, VIII. Al Giftun1, IX. Al Giftun 2, X. Kiriazi XI. Abo Tartoor, XII. Safaga, XIII. Al Hamraween XIV. Marsa Ghaleb, XV. Marsa Alam, XVI. Wadi El Gemal Island, XVII. Sharm El Luli, XVIII. Um El Abas, XIX. Al Qulaan, XX. Hamata and XXI. Shalateen.

\section{Nematodes analysis}

Nematodes samples were collected using hand made metal corer with $3.6 \mathrm{~cm}$ internal diameter of 3.6 and total inner area of $10 \mathrm{~cm}^{2}$. Nine samples per site were collected during January 2006. The sampling regime was designed to cover different littoral zones (Supralittoral, Eulittoral and Sublittoral zones). At each zone, 3 
replicates of core samples were taken and the obtained sediment was preserved in $4 \%$ neutralized formaldehyde solution with Rose Bengal stain $(0.5 \mathrm{~g} / 1)$. In the laboratory, they were passed through two sieves, the top one with a mesh size of $500 \mu \mathrm{m}$ (captured meiobenthic organisms) while bottom one had a mesh size of $50 \mu \mathrm{m}$. Organisms retained on the lower sieve were considered as meiobenthos (Heip et al., 1979). All samples were counted under binocular stereomicroscope (Prior, S2000) at magnification of 10X.

Identified nematodes were picked up with an eyebrow hair glued to a stick from each sample. The organisms were transferred to $5 \%$ aqueous glycerol in a small watch glass then placed in an oven at 40 ${ }^{\circ} \mathrm{C}$ until the water had evaporated leaving the organisms in pure glycerol. The organisms were picked up again and transferred to a drop of anhydrous glycerol on a microscope slide, covered with an appropriate sized glass cover, then examined with an oil immersion lens (X 100). Identification of nematodes was performed using the keys of Tarjan (1980); Platt and Warwick (1983); Platt and Warwick (1988) and Warwick et al. (1998).

\section{Data analysis}

Two-Ways analysis of variance was used to test the significant differences in abundance of nematodes between sites and zones. The interactions between two factors were applied, using SYSTAT program (V.10.2.05, 2002). Spearman's correlation coefficient $(\rho)$ was used to determine any significant correlations between the total nematodes densities and the sediment grain size, TOMs by using computer software (SYSTAT; V.10.2.05, 2002).

\section{Measured Parameters}

\section{RESULTS}

All physico-chemical parameters and sediment characteristics are listed in Table (1). The area of study was characterized by high temperature, high salinity, alkaline water and low oxygen saturation level. The granulometry of sediments was coarse in their nature, their grain size ranged between -2.07 as estimated for Marsa Ghaleb and +0.6 calculated for Abo-Menqar mangrove (according to Wentworth scale, i.e. $\varphi$ ). Low amount of TOMs for all sediment samples were recorded and found to be high at Al Azaq Al Qadeem and Al Gemsha sites (11.9 and 10.9 respectively). In contrast, Abo Tartoor exhibited the lowest value of TOMs overall investigated in this study (being $3.2 \mathrm{mg} / \mathrm{g}$ ). Also, redox potential values were recorded and ranged between 33.3 and $363 \mathrm{mV}$.

\section{Nematode distribution}

Nematoda was found at every investigated site and dominated all interstitial taxa. Nematoda was the most abundant group contributing 
for about $66 \%$ of total interstitial meiobenthos, their contribution ranged between 38.7\% (Abo Menqar mangrove) and 100\% (Al Azaq Al Qadeem) (Fig. 2).

Table 1: Water temperature $\mathrm{T}\left({ }^{\circ} \mathrm{C}\right)$, water salinity $(\%), \mathrm{pH}$, dissolved oxygen $\left(\mathrm{DO}_{2}-\mathrm{mg} / \mathrm{g}\right)$, median grain size $(\mathrm{Mz}-\varphi)$, total organic matters (TOMs) and Redox potential (Eh) for each site during the general survey (January 2006).

\begin{tabular}{|c|c|c|c|c|c|c|c|}
\hline \multirow{2}{*}{ Site/parameter } & $\mathbf{T}\left({ }^{\circ} \mathrm{C}\right)$ & $\begin{array}{c}\text { Salinity } \\
(\%)\end{array}$ & pH & $\mathrm{DO}_{2}$ & $\operatorname{Mz}(\varphi)$ & TOMs(mg/g) & $E h(m V)$ \\
\hline & average & average & & & average & average & average \\
\hline Gabal El-Zeit & $19.7 \pm 0.8$ & $42 \pm 0.3$ & 8.2 & 5.3 & $0.17 \pm 0.9$ & $4.1 \pm 1.1$ & $46.7 \pm 25.2$ \\
\hline Al-Gemsha & $21.2 \pm 1$ & $43.5 \pm 0.5$ & 8.2 & 5.5 & $0.03 \pm 0.6$ & $10.9 \pm 2.6$ & $156.6 \pm 40.4$ \\
\hline Sama Beach & $21.2 \pm 1$ & $42 \pm 0.3$ & 8.3 & 5.6 & $0.07 \pm 0.6$ & $5.1 \pm 1.4$ & $183.3 \pm 35.1$ \\
\hline Al-Azaq Al-Qadeem & $19.7 \pm 0.6$ & $39 \pm 0.8$ & 7.4 & 5.1 & $0.5 \pm 0.62$ & $11.9 \pm 5.7$ & $33.3 \pm 15.3$ \\
\hline Helnan Regena & 21 & $42 \pm 0.3$ & 8.2 & 5.6 & $-1.9 \pm 0.9$ & $5 \pm 2$ & $276.7 \pm 25.2$ \\
\hline El-Gifton 1 & $21.2 \pm 0.3$ & 42 & 8.2 & 5.6 & $-1.27 \pm 1.4$ & $3.9 \pm 1.3$ & $320 \pm 40$ \\
\hline El-Gifton 2 & $21.2 \pm 0.3$ & 42 & 8.2 & 5.6 & $-1.23 \pm 0.9$ & $5.4 \pm 2.7$ & $310 \pm 10$ \\
\hline Abo-Menqar Island & $22.2 \pm 0.3$ & $42 \pm 0.6$ & 8.2 & 5.7 & $-0.03 \pm 0.7$ & $6.3 \pm 1.7$ & $260 \pm 53$ \\
\hline Abo-Menqar mangrove & $21.8 \pm 0.6$ & $42 \pm 1.2$ & 7.8 & 5.1 & $0.6 \pm 0.9$ & $7 \pm 1.4$ & $133 \pm 25.2$ \\
\hline Kiriazi & $21.7 \pm 0.6$ & $41 \pm 0.3$ & 8.2 & 5.4 & $-0.97 \pm 1.4$ & $3.4 \pm 0.9$ & $240 \pm 40$ \\
\hline Safaga & $21.7 \pm 0.6$ & 43 & 7.6 & 4.8 & $0.43 \pm 0.4$ & $5.3 \pm 2.7$ & $120 \pm 21$ \\
\hline Abo-Tartoor & 21 & 41 & 8.2 & 5.6 & $-1.97 \pm 1.3$ & $3.2 \pm 0.8$ & $363.3 \pm 15.3$ \\
\hline Al-Hamraween & $21.5 \pm 0.3$ & 40.5 & 8.4 & 5.5 & $-0.57 \pm 1$ & $8.5 \pm 3.8$ & $173.3 \pm 42$ \\
\hline Marsa Ghaleb & $21.2 \pm 0.6$ & $41 \pm 0.3$ & 8.3 & 5.4 & $-2.07 \pm 0.1$ & $10.3 \pm 2.5$ & $286.7 \pm 35$ \\
\hline Marsa Alam & $21.7 \pm 0.6$ & $41 \pm 0.3$ & 8.2 & 5.3 & $-0.93 \pm 1.3$ & $3.5 \pm 0.8$ & $246.7 \pm 35$ \\
\hline Wadi El-Gemal Island & $21.7 \pm 0.6$ & 40 & 8.2 & 5.5 & $-0.6 \pm 1.4$ & $6.6 \pm 2.4$ & $293.3 \pm 31$ \\
\hline Um El-Abas & $21.7 \pm 0.6$ & $40.5 \pm 0.3$ & 8.2 & 5.5 & $0.37 \pm 0.2$ & $7.3 \pm 3.8$ & $266.7 \pm 25.257$ \\
\hline Sharm El-Luli & $21.7 \pm 0.6$ & $41 \pm 0.3$ & 8.3 & 5.2 & $-1.1 \pm 1.2$ & $6.4 \pm 3$ & $303.3 \pm 25.2$ \\
\hline Al-Qulaan & $21.7 \pm 0.6$ & $43 \pm 0.3$ & 7.7 & 5.1 & $-0.97 \pm 0.5$ & $7.9 \pm 3.3$ & $273.3 \pm 25.2$ \\
\hline Hamata & $21.7 \pm 0.6$ & 40 & 8.2 & 5.3 & $-0.53 \pm 0.4$ & $5.3 \pm 1.8$ & $256.7 \pm 68$ \\
\hline Shalateen & $23.2 \pm 0.8$ & $39.5 \pm 1.3$ & 8.2 & 4.9 & $0.1 \pm 0.2$ & $9.1 \pm 4$ & $260 \pm 17.3$ \\
\hline
\end{tabular}




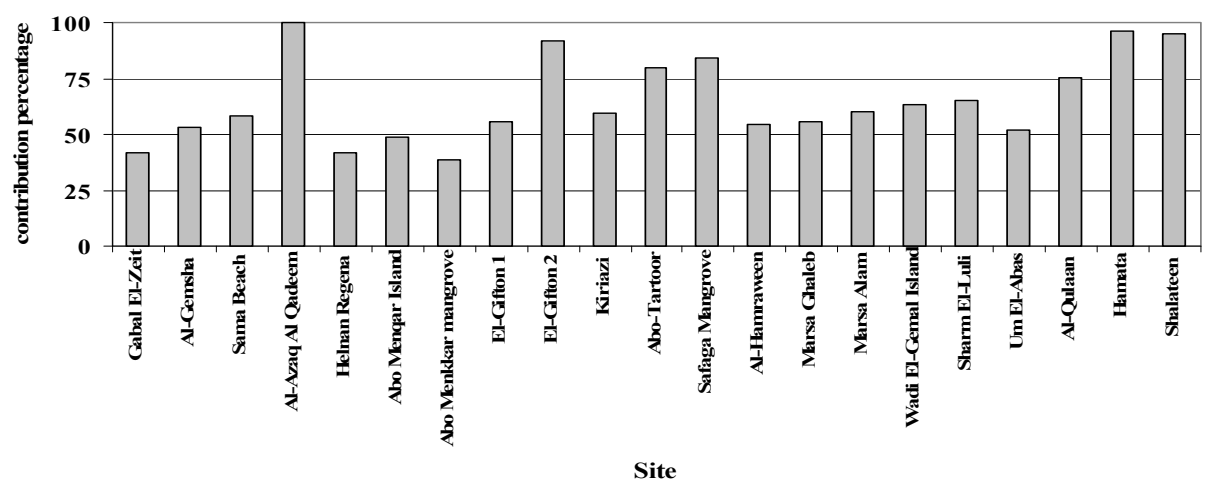

Fig. 2: Contribution percentage of nematodes within other interstitial groups at all investigated sites.

Regarding the abundance of nematodes at different investigated sites, Al Gemsha exhibited the highest densities of these organisms with an overall mean value of $163.2 \pm 97.7$ organisms $/ 10 \mathrm{~cm}^{2}$. In contrast, the lowest abundance was estimated for Al Azaq Al Qadeem (8.1 17.6 organisms $/ 10 \mathrm{~cm}^{2}$ ). Marsa Alam and Gabal El Zeit showed very low densities of nematodes $\left(16.7 \pm 13.8\right.$ and $19.6 \pm 24.9$ organisms $/ 10 \mathrm{~cm}^{2}$ respectively (Fig. 3). The nematode community varied greatly from one site to another; Two ways ANOVA test showed that the effect of site on the total density of nematodes was significant $(P<0.001)$ (Table 2$)$.

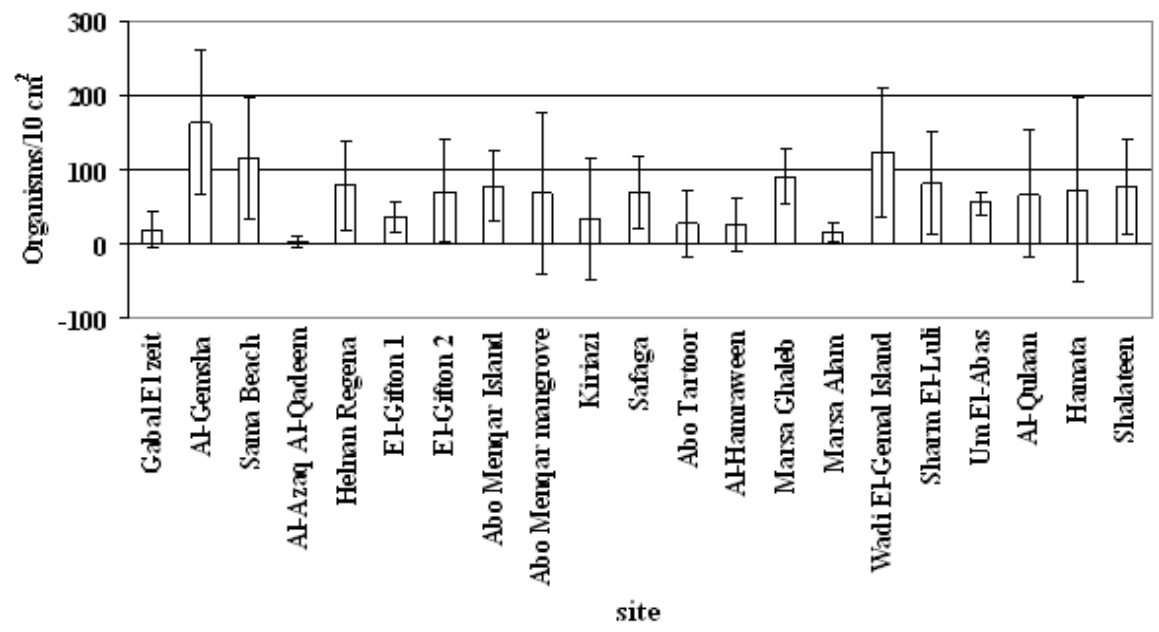

Fig. 3: Abundance of nematodes at all investigated sites

With regard to the occurrence of nematodes in the different littoral zones, similar values of overall mean of density values were estimated for the supralittoral and eulittoral zone $57.9 \pm 44.5$ 
organisms $/ 10 \mathrm{~cm}^{2}$ (Fig. 4). This value was lower compared to the sublittoral zone (average $81.3 \pm 60.9$ organisms $/ 10 \mathrm{~cm}^{2}$ ). However, the ANOVA analysis performed on effect of zones on the total density of nematodes was significant $(P<0.001)$ (Table 2$)$.

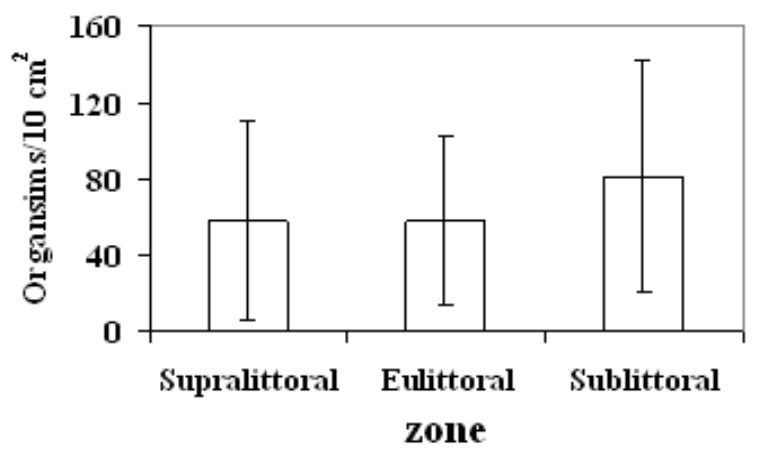

Fig. 4: Abundance of nematodes according to their density at different littoral zones

Table 2: Two ways analysis of variance (ANOVA) performed on the effect of site and zone on the density of Nematoda.

\begin{tabular}{lccccc}
\hline $\begin{array}{l}\text { Source of } \\
\text { variation }\end{array}$ & $\begin{array}{c}\text { Sum-of- } \\
\text { Squares }\end{array}$ & $\boldsymbol{d f}$ & $\begin{array}{c}\text { Mean- } \\
\text { Square }\end{array}$ & F-ratio & P value \\
\hline Site & 542448.942 & 20 & 27122.45 & 86.272 & 0.000 \\
Zone & 46138.926 & 2 & 23069.46 & 73.38 & 0.000 \\
Site* Zone & 471270.63 & 40 & 11781.77 & 37.476 & 0.000 \\
$d f:$ degree of freedom & $P$ value $=$ level of significance at 0.05 level
\end{tabular}

The correlation between nematodes abundance and sediment texture $(\mathrm{Mz}$ value) showed a significantly weak positive correlation (0.21, $P$ value $=0.049)$, while a reasonable positive significant correlation with the TOMs was detected $(\mathrm{R}=0.54, P$ value $=0.05)$.

Species composition of free living nematodes community

Nematodes community was represented by 79 species belonging to 58 genera, 28 families and 5 orders (Appendix 1). Enoplida formed about $42 \%$ of total nematode count, while Areolaimida was the lowest order in terms of abundance and represented by only one species constituting about $4 \%$ of total nematode count in this current work.

Xyalid and oncholaimid nematodes were the most abundant nematode families that contributed $12 \%$ for each one of the total nematodes in the area of study (Fig. 5). In contrast, Axonolaimid and enoplid nematodes were the lowest families in the order of density contributing $0.7 \%$ of total nematode count 


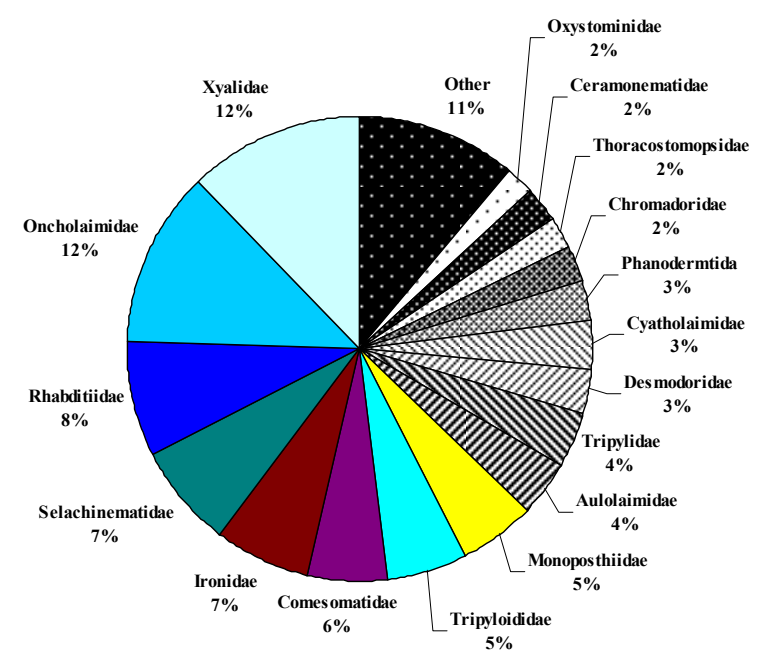

Fig. 5: Contribution percentage for all families of recorded nematodes.

Twenty nine species formed $75 \%$ of total nematodes count that were dominated by two families namely; Xyalidae and Oncholaimidae. The densities of these species at all investigated sites were recorded in Table (3). Out of them, 11 species were found to be dominating all nematode species and formed about $50 \%$ of total nematode count in this study. These species were: Theristus clax (10.5\%), Ptycholaimellus ponticus (6.3\%), Cheironchus sp. (5\%), Oncholaimus brachycercus (4.2\%), Aulolaimus oxycephalus (3.8\%), Tripyloides marinus (3.5\%), Dolicholaimus marrioni (3.5 \%), Monoposthia costata (3.4 \%), Viscosia abyssorum (3.1\%), Tobrila imberbis (3\%), Rhabditis marina $(2.3 \%)$ and Crenopharynx marioni $(2.3 \%)$. The contributions of other nematode species ranged between $0.15 \%$ and $0.9 \%$ of total nematode count. Theristus clax was the most abundant species and exhibited the maximum density value overall nematode populations with overall mean density of 35 individuals $/ 10 \mathrm{~cm}^{2}$ at $\mathrm{Al}$ Gemsha, while this species was recorded at 11 sites (Table 3 ).

The recorded nematode species varied among sites, the maximum recorded nematode species were found at Al Qulaan (19 species). In contrast, Marsa Alam and Kiriazi showed the minimum recorded nematode species (3 spp). Also, Gabal El Zeit and Al Azaq Al Qadeen were inhabited by low number of nematode species (being 5 species) (Fig. 6). 
Table 3: Average density value of the common nematode species expressed as number of individual $/ 10 \mathrm{~cm}^{2}$ of all sites.

\begin{tabular}{|c|c|c|c|c|c|c|c|c|c|c|c|c|c|c|c|c|c|c|c|c|c|}
\hline Taxalsites & 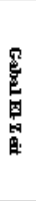 & 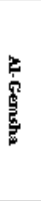 & 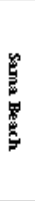 & $\begin{array}{l}\mathbf{B} \\
\mathbf{E} \\
\mathbf{E}\end{array}$ & 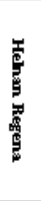 & 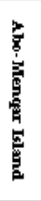 & 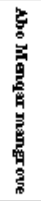 & 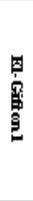 & 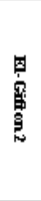 & 睍 & 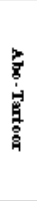 & $\begin{array}{l}\text { 总 } \\
\text { 要 }\end{array}$ & $\begin{array}{l}3 \\
7 \\
7\end{array}$ & 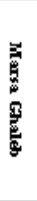 & 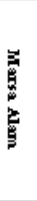 & 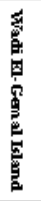 & 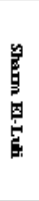 & 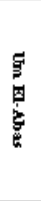 & 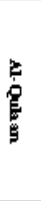 & $\begin{array}{l}\mathbf{T} \\
\vec{E}\end{array}$ & 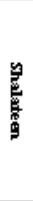 \\
\hline Enoplolamus subterraneus & - & - & - & - & - & - & - & - & - & - & - & - & 6 & - & - & 11 & 4 & - & - & - & - \\
\hline Anoplos toma vivpanm & - & - & 6 & 0.4 & - & 4 & - & - & - & - & 5 & - & - & - & - & - & - & - & - & - & - \\
\hline Geropkopynx mariori & - & 8 & - & - & - & 4 & 2 & - & - & 6 & - & - & - & - & - & 6 & 5 & - & - & - & - \\
\hline Dolichloinus mamioni & - & - & - & - & - & - & - & - & - & 8 & 4 & - & - & 23 & - & - & - & 4 & 9 & - & - \\
\hline Syingolainus filicaudatus & - & - & - & - & - & - & - & - & - & - & - & - & - & 10 & - & - & - & - & 5 & - & - \\
\hline Wpingolaimus smarigdus & - & 14 & - & - & - & - & - & - & - & - & - & - & - & - & - & - & 5 & 4 & - & - & - \\
\hline Thorosostoma microlobotum & - & 10 & 6 & - & - & - & - & - & - & - & - & - & - & - & - & - & - & - & - & - & - \\
\hline Foldoimus longocoudous & 4 & - & - & - & - & $T$ & - & - & - & - & - & - & - & - & - & - & - & - & - & - & 7 \\
\hline Onoholainus bolpyerous & - & - & 8 & - & 4 & - & - & 8 & 25 & - & 6 & - & - & - & - & & 7 & - & - & - & - \\
\hline Viscosia obysorom & & & & & 4 & & & 3 & $y$ & & & 4 & & 10 & 9 & & & 5 & & & \\
\hline Gyptonelus abromis & - & - & - & - & - & - & - & - & - & - & - & - & 13 & - & - & - & 4 & - & - & - & - \\
\hline Tokilaimberbs & - & - & 7 & - & 4 & - & - & - & - & - & - & 5 & 2 & - & - & - & - & - & - & 18 & 6 \\
\hline Tripploides marinus & - & 7 & 25 & - & - & 3 & - & 3 & 4 & - & - & - & - & - & - & - & - & - & - & - & 6 \\
\hline Fycholaimellus porticus & - & 18 & 11 & - & - & - & 4 & 4 & - & - & 7 & 14 & 3 & - & - & - & 19 & - & - & 6 & - \\
\hline Hopperia sp. & - & - & 5 & - & - & - & - & 3 & 5 & - & - & - & - & - & 3 & - & - & - & - & 7 & - \\
\hline Gotholamus pringi & - & - & - & - & 8 & - & - & 3 & 5 & - & - & - & - & - & - & - & - & - & - & - & - \\
\hline Mapplymia sp & - & - & - & - & - & - & - & - & - & - & - & - & - & - & - & - & - & - & 9 & 5 & 6 \\
\hline Geironolus sp. & 5 & 19 & 11 & & 10 & 18 & - & - & - & - & - & - & - & - & - & - & 4 & - & - & - & - \\
\hline Holichonolainus mingr & 4 & - & - & - & - & - & - & - & - & - & - & - & - & - & 3 & - & 5 & 5 & - & - & - \\
\hline Catomema macinplyei & - & - & - & - & - & 3 & 3 & - & - & - & - & - & - & - & - & - & - & - & - & & 15 \\
\hline Gromaspininasp. & - & - & - & - & - & 5 & 2 & - & - & - & - & - & - & - & - & 13 & - & - & 2 & - & - \\
\hline Sirino schneideri & - & - & 6 & - & - & - & - & - & - & - & - & - & - & - & - & 9 & - & - & - & - & - \\
\hline Monopos thia anonoposthia & - & - & - & - & - & - & - & - & - & - & - & - & - & 17 & - & 5 & - & - & - & - & - \\
\hline Monopos thia costata & - & 8 & - & $0 . T$ & 3 & 11 & 18 & - & - & - & - & & - & - & - & - & - & 3 & 3 & - & - \\
\hline Dosynemaxides absonsis & - & - & - & - & 6 & 4 & & 3 & 4 & - & - & - & - & - & - & - & - & 4 & 2 & - & - \\
\hline Theristu clax & - & 35 & 8 & - & 15 & - & $y$ & 4 & 6 & 15 & 8 & 15 & - & IT & - & - & 13 & - & - & - & - \\
\hline Phordamus marouiroulus & - & - & - & - & - & - & - & - & - & $T$ & - & - & - & - & - & - & - & - & - & 15 & 7 \\
\hline Auloloinss opcepholu & - & 12 & 7 & - & - & - & - & - & - & - & - & 13 & - & - & - & - & 6 & 11 & 3 & - & - \\
\hline Fubbatis marna & - & - & - & - & - & - & 3 & 3 & 5 & & & 7 & - & - & - & - & 5 & 5 & 4 & - & - \\
\hline
\end{tabular}

Legend (-) means no record.

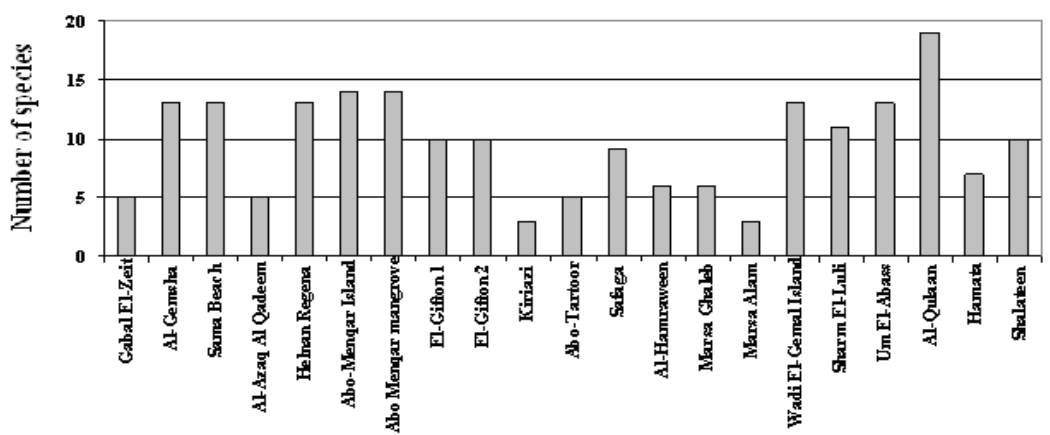

Site

Fig. 6: Total number of nematode species recorded at all investigated sites. 


\section{DISCUSSION}

Nematodes usually dominate all marine meiofaunal samples in abundance and biomass occurring in each substrate and sediment in all climatic zones, where they are of considerable ecological importance. All free living nematodes are of meiobenthic size. In their general body structure they are in many respects; preadapted to live in sands and muds (Platt and Warwick, 1980).

In the present work, nematodes densities were varied among sites. High density of nematodes at Safaga may be due to its characteristic sheltered nature with a relatively high ratio of silt and clay sediment. Nematodes seem to be controlled by the percentage of fine sand sediments, since their abundance was positively correlated with fine sand $(\mathrm{R}=0.21, P=0.05)$. On the other hand, Marsa Alam exhibited the lowest density of nematodes that might be attributed to the presence of high level of coarse sand and it is considered the most exposed beach to wave action among the investigated sites. Similar findings were concluded by Vitiello (1968); Findlay (1981) and Coull (1985) who found that fine sediments typically have more nematodes than coarser sediments.

Nematodes exhibited high densities in the sublittoral zones during this study. A similar finding was reported by Schmidt and Westheide (1969) who studied the macrofauna and meiofauna of tidal beaches on the island of Sylt in the North Sea and found that the numbers of meiofauna diminished from low water towards high water mark.

In the current study, total organic matter (TOMs) was found to play an important role in meiofaunal distribution of the investigated sites. Al Gemsha, Safaga and Al Qulaan were inhabited by more abundant nematodes among all investigated sites which are correlated with their high values of TOMs among all sites. Lee et al. (1980); Tenore and Rice (1980) and McLachlan et al. (1981) confirmed that the content of organic matter has a significant influence on abundance of the interstitial organisms.

Out of all sites, 2 sites showed a different pattern of relationship with TOMs and meiobenthic abundance. Wadi El Gemal Island exhibited high density of nematodes and relatively low TOMs, whereas Al Hamraween showed relatively high TOMs and low densities of these organisms. The density of total free living nematodes in this study revealed a weak positive relationship with the percentage of TOMs. Lack of strong relationships of their densities and the sediment characteristics may be referred to the different preferred habitat for each group of meiofauna or for each meiobenthic species (Thompson and Jones, 1987). The inverse relationship between TOMs content and meiofaunal densities indicated that either meiofauna are not food 
limiting, or TOMs does not measure food quality, or other factors might regulate density (Montagna, 1991).

In the present study, Al Qulaan that lies at Wadi El Gemal protectorate area has a moderate length of intertidal flat with relatively rich seaweed and seagrasses cover (different plant populations). Its meiofaunal community was the most diversified and the richest, due to the latter factors in addition to being away enough from any human impact from any sort. All these conditionS can significantly enhance the health of the meiofaunal community. Besides, Al Gemsha and Marsa Ghaleb were inhabited by relatively abundant and diverse meiobenthic community rather than those found in adjacent locations with nearly similar environmental conditions namely; Gabal El Zeit, Al Hamraween and Marsa Alam. Hicks (1985) stated that macroalgae provide three subhabitats, for meiofauna; the surface of the thallus fronds, the sediment and detritus deposits accumulating at the base of the fronds and the interstices of hold fasts.

In the current study, the abundance of sites with phytal complex ranged from 2 to 4 times that recorded for other sites, lacking any vegetation. Similar findings were observed by Mohammed (2004) and Mohamed (2010) in the Egyptian Red Sea where they found high densities of benthic invertebrates in the seagrass beds and attributed that to the availability of food. Ansari (1993) found that the seagrass bed enhances microalgal (diatoms) and bacterial productivity. Also, Fenchel (1970) and Ingole et al. (1987) observed that the increase of detritus, which provides the main food for meiofauna, is suggested to be the reason for the meiofauna densities in the seagrass bed.

The saturation level of oxygen represents another important factor influencing the structural and functional ecology of meibenthic organisms. In the present study, the oxygen saturation level was low in general at all investigated sites. Similar ranges of dissolved oxygen were reported by Edwards (1987). Red Sea species must be adapted to low oxygen saturation levels overall any water body at the same latitudes (due to high temperature, high salinity and low primary production).

In the current study, nematodes dominated all interstitial groups of metazoan invertebrates that might be due to their minimum demands of oxygen than other interstitial groups. This explanation might be ascertained by their dominances in the collected sediment samples in the area of study. Herman et al. (1985) found that the respiration rate of nematode worms was the lowest among all interstitial forms.

The obtained results indicate that all these factors affect the abundance and diversity of meiobenthic organisms in the area of study (with low density and high diversity) characterized by coarse grain sediment and low TOMs. On the contrary, Mohammed (2004) found 
that meiobenthic community of the Suez Canal and the Mediterranean Sea showed high meiofaunal density and low diversity in fine grain size and high TOMs sediments.

Land-filling and urbanization of the Red Sea beaches adversely affect on the meiobenthic community structure in terms of diversity and abundance (Giere, 2009). In the current study, Kiriazi showed low density of nematodes rather than poor diversity among all the studied sites that might be due to the effect of newly landfilling processes at this site.

In the current study, the interstitial meiobenthic community of Al Azaq Al Qadeem site (with different pollutants found in the littoral area of this site) was represented by five species of nematodes. Hodda and Nicholas (1985) observed that meiofaunal density decreased with increasing pollution. In the present study, very low density of meiobenthos in general and nematodes in particular was observed in $\mathrm{Al}$ Azaq Al Qadeem which was organically enriched due to human impacts and harbor activities.

Heip and Decramer (1974) related the local decrease in nematode diversity with the efflux of polluted water. However, the influence of concomitant factors like changes in sediment structure, may interfere, and thus complicate the interpretation of diversity indices. Gray and Ventilla, (1971) and Moore and Bett, (1989) stated that nematodes are known to be relatively resistant to many types of pollutants and the highest species number of nematodes even within small samples renders them good indicators for disturbance and pollution induced change. Also, many studies found that in acutely impacted areas with crude or refined fuel oil, nematodes have shown rapid density recoveries in three months or less (Wormald, 1976; Giere, 1979; Boucher et al., 1981, 1984; Elmgren et al., 1983).

Redox potential was another parameter affecting the abundance of the interstitial forms in general and nematodes in particular. The effect of this parameter was minimal at Al Azaq Al Qadeem site which exhibited very low density value in this study. Similar results were observed by Dye and Furstemberg (1978) and Dye (1979) who found a direct relation between decreasing Redox potentials and decreasing meiofaunal abundance in South Africa shores.

\section{AKNOWLEDGMENT}

We would like to thank all members of the Red Sea protectorates at Hurghada, Marsa Alam. Wadi El Gemal, Hamata and Shalateen areas. Sampling could not have been completed without their kind assistance. 


\section{REFERENCES}

Ansari, Z. A. and Parulekar, A. H. (1993). Distribution, abundance and ecology of the meiofauna in a tropical estuary along the west coast. Hydrobiol., 262: 115-126.

Blome, D. (1983). Okologie der Nematoda eines Sandstrandes der Nordseeinsel Sylt. Mikr. Meer., 88: 1- 76.

Boucher, G. (1981). Effect of a long terme des hydrocarbues de l' Amoco Cadiz Sur la structure des communates de nematodes libres des sables fins sublittoraux. In: Amoco Cadiz. Consequences d' un pollution Accidentelle par les Hydrocarbures., Actes coll. Intern. C. O. B. Brest (France) 19-22. Nov. 1979, Ed. CNEXO, Paris, pp. 539-549

Castel, J. (1992). The meiofauna of coastal lagoon ecosystems and their importance in the food web. Vie. Milieu, 42: 125-135.

Dinet, A, Grassle, F. and Tunnicliffe, V. (1988). Premires observation sur la meiofauna des sites hydrothermaux de la dorsale EstPacifique (Guaymas, $21^{\circ} \mathrm{N}$ ) et de l'Explorer Ridge. Oceanol. Acta., 85: 7-14.

Dye, A. and Furstenberg, J. (1978). An ecophysiological study of the meiofauna of the Swartskops Estuary. 2. The meiofauna: composition, distribution, seasonal fluctuation and biomass, Zool. Afr., 13:19 pp.

Dye, A. H. (1979). Aspects of the ecology of meiofauna in Morgazana estuary Transkei, S. Afr. Tydskr. Dierk., 14: 67 pp.

Elmegren, R.; Hansson, S.; Lasson, U; Sundelin, B. and Boehm, P. (1983). The "Tsesis" oil spill: acute and long-term impact on the benthos. Mar. Biol. Publ. 12, Szczecin, Poland, 20 pp.

Faubel, A. (1984). On the abundance and activity pattern of zoobenthos inhabiting a tropical reef area, Cebu, Philippines. Coral Reefs, 3: 205-213.

Fenchel, T. (1970). Studies on the decomposition of detritus derived from the turtle grass Thalassia testudinium. Limnol. Oceanogr., 15: $14-20$.

Folk, R. L. and Ward, W. C. (1957). Brazos River bar: a study in significance of grain -size parameters, Sedimentol., 6: 73-93.

Giere, O. (2009). Meiobenthology: The microscopic fauna in aquatic sediments. Springer-Verlag. Berlin. 
Giere, O. (1979). The impact of oil pollution on intertidal meiofauna Field studies of the La Coruna-spill. Chiersde Biologie Marine., pp. 231-251

Gray, J. S. and Ventilla, R. J.(1971). Pollution effects on micro- and meiofauna of sand. Mar. Pollut. Bull., 2: 39-43.

Grelet, Y., Falconetti, B. A. Thomassin P. \& Vitiello A. H. and Abu Hilal, (1987). Distribution of the macro-and meiobenthic assemblages in the littoral soft-bottoms of the Gulf of Aqaba (Jordan). Atoll Res. Bull., 308: 1-27.

Heip, C. and Decraemer, W. (1974). The diversity of nematode communities in the southern North Sea. J. Mar. Biol. Ass. U.K., 54: 251-255.

Heip, C.; Vincx, M. and Vranken, G. (1985). The ecology of marine nematodes. Ocean. and Mar. Biol. Ann. Rev., 23: 399-489.

Herman, R. Vincx, M. and Heip, C. (1985). In, Biological processes and Translocations, Vol., 3, edited by Heip, C. and Polk, P. Min. Sci. Policy, Brussels, pp. 41-63.

Hicks, G. R. (1985). Meiofauna associated with rocky shore algae. In. Moore, P. G., Seed, R. (eds). The ecology of rocky coasts. Hodder and Stoughton, London, pp. 36-64

Hodda, M. and Nicholas, W. L. (1985). Meiofauna associated with mangroves in the Hunter River estuary and Fullerton Cove, southeastern Australia. Austr. J. of Mar. and Fresh. Res., 36(1): 41 - 50

Holme, N. A. and McIntyre. A. D. (Eds.). (1984). Methods for the study of marine benthos, $2^{\text {nd }}$ edition Blackwell Oxford, $387 \mathrm{pp}$.

Jones, D. A;.Ghamrawy M.; and.Wahbeh. M. I (1987). Littoral and shallow subtidal environments .In. Red Sea Key Environments. (edts.) Edwards, A. J. and Head, S. H., lst edition.pergamon press, $441 \mathrm{pp}$.

Lee, W. Y.; Morris, A. and Boatwright, D. (1980). Mexican oil spill: a toxicity study of oil accommodated in seawater on marine invertebrates. Mar. Pollut. Bull., 11: 231-234.

McLachlan, A. (1980). The definition of sandy beaches in relation to exposure: a simple rating system. S. Afr. J. Sci., 76: 137-138.

McLachlan, A. and Jaramillo, E. (1995). Zonation on sandy beach. Oceanogr. and Mar. Biol. Ann. Rev., 33: 305-335 
Mohamed, E. O. (2010), Ecological studies on fauna associated with seagrass habitat at Hurghada-Red Sea. M. Sc. Thesis, Faculty of Science, Al Azhar University, 222 pp.

Mohammed, D. A. (2004). Ecological studies on the small eu-metazoan benthic invertebrates (meiobenthos) in the Suez Canal area. M. Sc. Thesis. Suez Canal University, Egypt, 292 pp.

Montagna, D. A. (1991). Meiobenthic communities of the Santa Maria Basin. California continental shelf research, 11: 1355-1378.

Moore, C. G. and Bett, B. J. (1989). The use of meiofauna in marine pollution impact assessment. Zool. J. Linn. Soc., 96: 263-280.

Nair, A. (1978). Production ecology of a tropical sandy beach at Benaulim, Goa. Indian J. Mar. Sci., 7: 163-167.

Nicholas, W. L. (2001) Seasonal variations in nematode assemblages on an Australian temperate ocean beach; the effect of heavy seas and unusually high tides. Hydrobiol., 464: 17-26.

Olafsson, E. (1991). Intertidal meiofauna on four sandy beaches in Iceland. Ophelia, 33: 55-65.

Platt, H. (1981). Meiofaunal dynamic and the origin of the metazoan. In: Greenwood P. H. (ed.). The evolving biosphere. Cambridge University Press, Cambridge, 207-216 pp.

Platt, H. M. and Warwick, R. M. (1980). The significance of free living nematodes to the littoral ecosystem. In, The shore Environment. 2. Ecosystem, Edited by Price, J. H. et al., Academic Press, New York, 729-759 pp.

Platt, H. M. and Warwick, R. M. (1983). Free living marine nematodes. Part I. British Enoplids. Synopses of the British Fauna No.28 (Eds. Kermack, D. and Barnes, R.) Cambridge University Press, Cambridge. 307 pp.

Platt, H. M. and Warwick, R. M. (1988) Free living marine nematodes. Part II. British Chromadorids. Synopses of the British Fauna No. 38 (Eds. Kermack, D.M. and Barnes, R. S. K.) E. J. Brill/Dr Backhuys, Leiden. 502 pp.

Rodriguez, J. G., Lopez, J. and Jaramillo, E. (2001). Community structure of the intertidal meiofauna along a graident of morphodynamic sandy beach types in southern Chile. Rev. Chil. Hist. Nat. 74: 885-897.

Srtickland, J. and Parson, T. (1968). A practical handbook of seawater analysis, Pigment analysis, Bull. Fish. Res. Bd. Canada, 167pp. 
Tarjan, A. C. (1980). Illustrated guide to the marine nematodes. IFAS, Univ. of Florida, Gainesville, $135 \mathrm{pp}$.

Tenore, K. R. and Rice, D. L. (1980). A review of trophic factors affecting secondary production of deposit-feeders. In Tenore, $\mathrm{K}$. R. and Coull, B. C. (eds) Marine benthic dynamics. University of South Columbia press. Columbia, Sc. 325-340 pp (Belle W Baruch Liber. Mar. Sci, 11).

Thompson, B. E. and Jones, G. F. (1987). Benthic macrofaunal assemblages of slope habitats in the Southern California borderland. Occasional papers of the Allen Hancock Foundation. New Series, 6: 11-21.

Vincx, M.; Meire, P. and Heip, C. (1990). The distribution of nematode communities in the Southern Bight of the North Sea. Cah. Biol. Mar., 31: 107-129.

Vitiello, P. (1968). Variation de la densite du microbenthos sur une aire restreinte, Rec. Trav. St. Mar. d Endoume, Bull., pp. 261-270

Warwick, R. M., Platt, H. M. and Somerfield, P. J. (1998). Free living marine nematodes. Part III. Monhysterids. Synopses of the British Fauna No.53. Linnean Society of London and the Estuarine and Coastal Sciences Association. ISBN 185153260 9. 295pp.

Wormald, A. P. (1976). Effects of a spill of marine diesel oil on the meiofauna of a sandy beach at Picin Bay, Hong Kong, Envir. Pollut., 11: 117-130. 


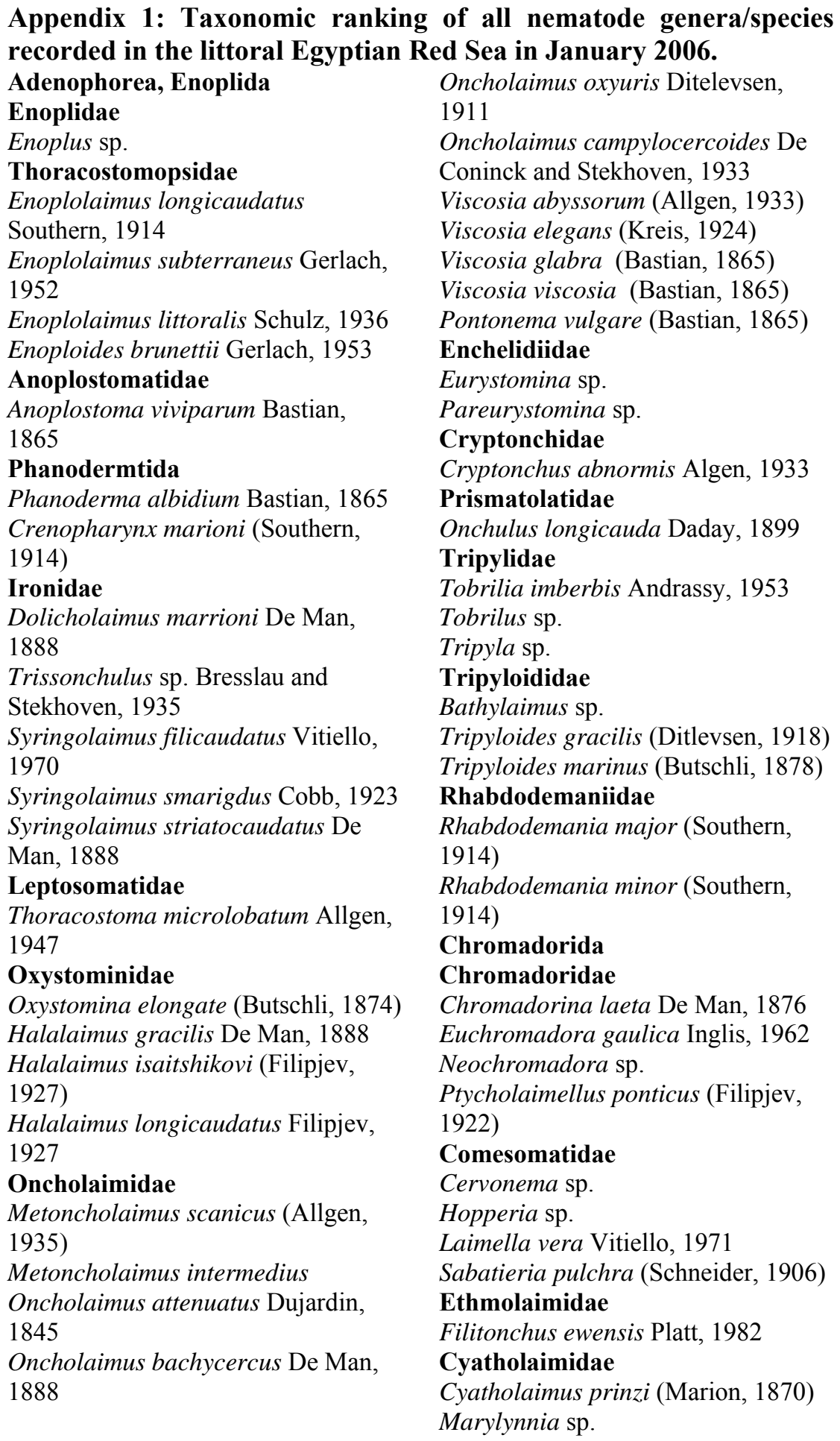


Paracyatholaimus sp.

\section{Selachinematidae}

Cheironchus sp.

Halichoanolaimus dolichurus

Ssaweljev, 1912

Halichoanolaimus minor Ssaweljev, 1912

Halichoanolaimus robustus (Bastian, 1865)

Desmodoridae

Catanema macintyrei Platt and

Zhang, 1982

Chromaspirina sp.

Spirina schneideri.(Villot, 1875)

Epsilonematidae

Epsilonema sp. Steiner, 1927

Draconematidae

Draconema sp

Dracogalerus sp. Allen \&

Noffsinger, 1978

Monoposthiidae

Monoposthia anonoposthia

Monoposthia costata (Bastian, 1865)

Haliplectidae

Haliplectus sp.

Ceramonematidae

Ceramonema carinatum

Ceramonema yunfengi Platt and

Zhang, 1982
Dasynemoides albaensis (Warwick

and Platt, 1973)

Desmoscolecidae

Desmoscolex sp.

Quadricoma sp.

Monhysterida

Xyalidae

Retrotheristus sp.

Theristus flevensis

Xyala impairs

Xyala riemann Boucher and

Helleauet, 1977

Sphaerolaimidae

Sphaerolaimus maeoticus Filipjev, 1918

Sphaerolaimus macrocirculus

Filipjev, 1918

Linhomoidae

Terschellingia sp.

Axonolaimidae

Axonolaimus sp.

Araeolaimida

Aulolaimidae

Aulolaimus oxycephalus De Man, 1988

Secernentea, Rhabditida

Rhabditidae

Rhabditinae

Rhabditis marina Bastian, 1865. 